\title{
貫通孔と鉄筋のカットオフを有する RC 梁の構造性能に関する実験的研究 EXPERIMENTAL STUDY ON STRUCTURAL PERFORMANCE OF RC BEAM WITH OPENING AND LONGITUDINAL CUT OFF BARS
}

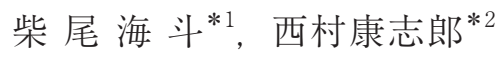 \\ Kaito SHIBAO and Koshiro NISHIMURA
}

\begin{abstract}
In this study, we investigated the influences of longitudinal bars cut off and lap splice in a beam with opening. We prepared three RC beam specimens and applied anti-symmetric bending in both positive and negative directions repeatedly and statically. Test parameters are the presence of openings and the presence of discontinuous points generated by cutting off bars or lap splicing. Consequently, the failure mode of the beams with opening were different from that of the beam without opening because the embedded part of the inclined reinforcement contributed to the resistance to shear load.
\end{abstract}

Keywords: reinforced concrete, beam with opening, multiple layered bar, cut-off bar, lap splice 鉄筋コンクリート，有孔梁，多段配筋，カットオフ筋，重破継手

1. 序

鉄筋コンクリート梁では，主筋のカットオフや継手のほか，配管 を通すための貫通孔を設けることがある。設計では，カットオフ筋 の付着, 通し筋の継手, 貫通孔のせん断耐力をそれぞれ検定するが, これらの複合的な影響はほとんど考慮されていない。貫通孔とカッ トオフ，重禅継手が近接すると互いに影響を及ぼし合うことが推測 される。また，鉄筋コンクリート構造計算規準・同解説 1) (以下, $\mathrm{RC}$ 規準) では，2010 年版に貫通孔を有する梁の許容せん断力式が 追加されたため，損傷制御性と残留ひび割れとの関係について実験 資料の蓄積も望まれる。

貫通孔を有する梁の研究は終局せん断耐力に関するものが多い。 松下らは貫通孔を有する梁のせん断耐力に関する多くの実験を行い, それらの実験結果をまとめ, せん断耐力式 2)を提案した。1970 年代 後半には, せん断耐力に与えるシアスパン比の影響を考慮するため, 松下らの提案した貫通孔による低減率を荒川 $\min$ 式 ${ }^{3)}$ に準用し, せ 几断耐力式の評価精度が検証された ${ }^{4)}$ 。この耐力式は現行の RC 規 準に採用されている。1990 年代, 津村は貫通孔を有する RC 梁のせ ん断耐力にせん断スパン比及び貫通孔位置が与える影響 5)や，鉄筋 の補強効果を極限解析により考察し, せん断耐力の計算方法 6)を示 した。それ以降, 貫通孔を有する $\mathrm{RC}$ 梁の研究は多くなく, 駿河ら による梁端部ヒンジ領域に貫通孔を有する RC 梁の曲げ耐力や勒性 能を確認する研究 7)や Dou らによる RC 梁端部ヒンジ領域の孔周囲 補強方法の開発に関する研究 8 )など梁端部ヒンジ領域に貫通孔を有 する $\mathrm{RC}$ 梁の研究が見られる程度である。貫通孔とカットオフ筋を
有する $\mathrm{RC}$ 部材の研究としては，石川らは梁端部に貫通孔を有する 梁の 2 段筋に機械式定着を用いたヒンジリロケーション柱梁接合部 に関する研究 9)を行っているが，貫通孔位置に発生する梁塑性ヒン ジ位置を，機械式定着を用いた梁 2 段筋により柱面から離すことで 貫通孔位置での破壊を防止するものであり，鉄筋のカットオフ，重 放継手，そして貫通孔の相互作用に関寸る研究は少ない。

このような背景から，本研究では，貫通孔を有する梁で，鉄筋の カットオフ，重赫手が与える影響を検討した。実験は，逆対称曲 げ載荷とした漸増繰り返し加力実験である。パラメータは貫通孔の 有無，鉄筋のカットオフ・重㸚継手の有無である。なお，本論文は 文献 10)の実験結果に考察を加えたものである。

\section{2. 実験計画}

\section{1 試験体および載荷システム}

Fig. 1 に試験体図を示す。試験体寸法は実物のおよそ $1 / 2$ を想定し たものを 3 体作成した。Table1 に試験体諸元, Table2, 3 にコンクリ ートと鉄筋の力学特性を示す。コンクリートには早強ポルトランド セメントを用いた。試験体は, 内法長さ $L$ が $2150 \mathrm{~mm}$, 梁断面が $300 \times 500 \mathrm{~mm}$, せん断スパン比 $L / 2 d$ が約 2.45 である。横補強筋は,

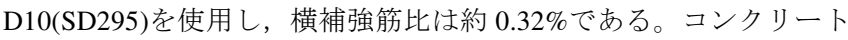
の打設は, 逆対称載荷時における上端筋と下端筋の付着強度に差が 生じるのを避けるために横打ちとした（Fig.1）。

パラメータは，貫通孔の有無， 2 段目主筋のカットオフ及び 1 段 目主筋の重社継手の有無とした。2 段目主筋を部材端部から $770 \mathrm{~mm}$
元 東京工業大学 大学院生・修士 (工学)

2 東京工業大学 准教授・博士 (工学)
Former Grad. Student, Tokyo Institute of Technology, M.Eng.

Assoc. Prof., Tokyo Institute of Technology, Dr.Eng. 
の位置でカットオフした。カットオフ筋の長さは, $\mathrm{RC}$ 規準 ${ }^{1)}$ の構造 規定に従い, カットオフ筋が計算上不要となる断面から有効せい延 長させた長さと同程度とした。重衫継手は, $\mathrm{RC}$ 規準 ${ }^{1)}$ の構造規定に 従って全数継手を避け, 1 段目主筋 4 本のうち 2 本に設けた。なお, 出隅鉄筋の重㸚継手では末端にフックが要求されるため, 配筋の都 合上， 1 段目中間 2 本に重禅継手を設けた。重㸚継手長さは， RC 規 淮の安全性の検定で要求される長さ程度になるように 730mm (コン クリートの設計基準強度 $27 \mathrm{MPa}$ で算出）とした。また, 塑性ヒンジ

Table1 List of specimens

\begin{tabular}{|c|c|c|c|c|}
\hline \multicolumn{2}{|c|}{ 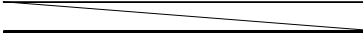 } & No.1 & No. 2 & No.3 \\
\hline \multicolumn{2}{|c|}{ Name of specimens } & DB2.5-w03-CL & DBO2.5-w09 & DBO2.5-w09-CL \\
\hline \multicolumn{2}{|c|}{ Width $\times$ depth $[\mathrm{mm}]$} & \multicolumn{3}{|c|}{$300 \times 500$} \\
\hline \multicolumn{2}{|c|}{ Clear span $[\mathrm{mm}]$} & \multicolumn{3}{|c|}{2150} \\
\hline \multicolumn{2}{|c|}{ Diameter of opening [mm] } & - & \multicolumn{2}{|c|}{165} \\
\hline \multirow{4}{*}{$\begin{array}{l}\text { Longitudinal } \\
\text { bar }\end{array}$} & Beam end region & 4,2-D19(SD345) & \multirow{2}{*}{ 4,2-D19(SD345 } & 4,2-D19(SD345) \\
\hline & Around mid-span & 4-D19(SD345) & & 4-D19(SD345) \\
\hline & $\begin{array}{l}\text { Development length of } \\
\text { inner (2nd) bar }\end{array}$ & 770 & - & 770 \\
\hline & Splice length [mm] & 730 & \begin{tabular}{|c|}
- \\
\end{tabular} & 730 \\
\hline \multirow{2}{*}{$\begin{array}{c}\text { Transverse } \\
\text { reinf. }\end{array}$} & No opening region & \multicolumn{3}{|c|}{ 2-D10@150(SD295) } \\
\hline & $p_{w}[\%]$ & \multicolumn{3}{|c|}{0.32} \\
\hline \multirow{3}{*}{$\begin{array}{c}\text { Reinf. around } \\
\text { opening }\end{array}$} & Transverse reinf. & - & \multicolumn{2}{|c|}{ 2-D10(SD295) } \\
\hline & Inclined reinf. & - & \multicolumn{2}{|c|}{ 4-D10(SD295) } \\
\hline & $p_{s}[\%]$ & - & \multicolumn{2}{|c|}{0.89} \\
\hline \multirow{2}{*}{$\begin{array}{c}\text { Test } \\
\text { parameter }\end{array}$} & Bar cut-off and lap splice & O & $x$ & 0 \\
\hline & Opening & $x$ & 0 & 0 \\
\hline
\end{tabular}

$p_{w}$ : transverse reinforcement ratio, $p_{s}$ : reinforcement ratio around opening 領域を避けるために，梁端から梁せい（500mm）離した位置から継 手を設けた。貫通孔を主筋のカットオフ位置のひび割れの影響を受 けやすい位置に 2 か所設け，無孔部と終局せん断強度が同程度にな るように孔周囲補強した。本論文では, 孔周囲の斜め補強筋を孔周 囲補強筋，孔際のあばら筋と無孔部のあばら筋を横補強筋と呼ぶこ ととする。Fig.1(e)の試験体 DBO2.5-w09-CL（Table1 の No.3）は貫 通孔と主筋のカットオフ・重ね継手を設けた試験体とした。試験体 名は梁形状-横補強筋形状-主筋形状からなり，それぞれの文字は $\mathrm{DB}(\mathrm{O})=$ Double layered Beam (with Opening) : 2 段筋 (貫通孔の有無)，

Table2 Mechanical properties of concrete

\begin{tabular}{c||c|c|c|c}
\hline Specimen & Age & $E_{c}$ & $\begin{array}{c}\text { Compressive strength } \\
\text { of cylinder, } \sigma_{B} \\
{[\mathrm{MPa}]}\end{array}$ & $\begin{array}{c}\text { Split tensile } \\
\text { strength, } \sigma_{t} \\
{[\mathrm{MPa}]}\end{array}$ \\
\hline DB2.5-w03-CL & 41 & 25.6 & 33.9 & 2.4 \\
\hline DBO2.5-w09 & 28 & 27.0 & 32.7 & 2.2 \\
\hline DBO2.5-w09-CL & 37 & 26.4 & 33.5 & 2.4 \\
\hline
\end{tabular}

$E_{c}$ : Secant modulus of elasticity at $1 / 3$ strength

\section{Table3 Mechanical properties of deformed bar}

\begin{tabular}{c|c|c|c|c|c}
\hline Reinforcment & $\begin{array}{c}\text { Nominal } \\
\text { diameter }\end{array}$ & Grade & $\begin{array}{c}E_{s} \\
{[\mathrm{GPa}]}\end{array}$ & $\begin{array}{c}\sigma_{y} \\
{[\mathrm{MPa}]}\end{array}$ & $\begin{array}{c}\sigma_{\max } \\
{[\mathrm{MPa}]}\end{array}$ \\
\hline Longitudinal reinforcement & $\mathrm{D} 19$ & $\mathrm{SD} 345$ & 186 & 357 & 540 \\
\hline Transverse and inclined reinforcement & $\mathrm{D} 10$ & SD295A & 187 & 360 & 523 \\
\hline$E_{s}:$ young's modulus, $\sigma_{y}:$ yield stress, $\sigma_{\max }:$ tensile strength
\end{tabular}

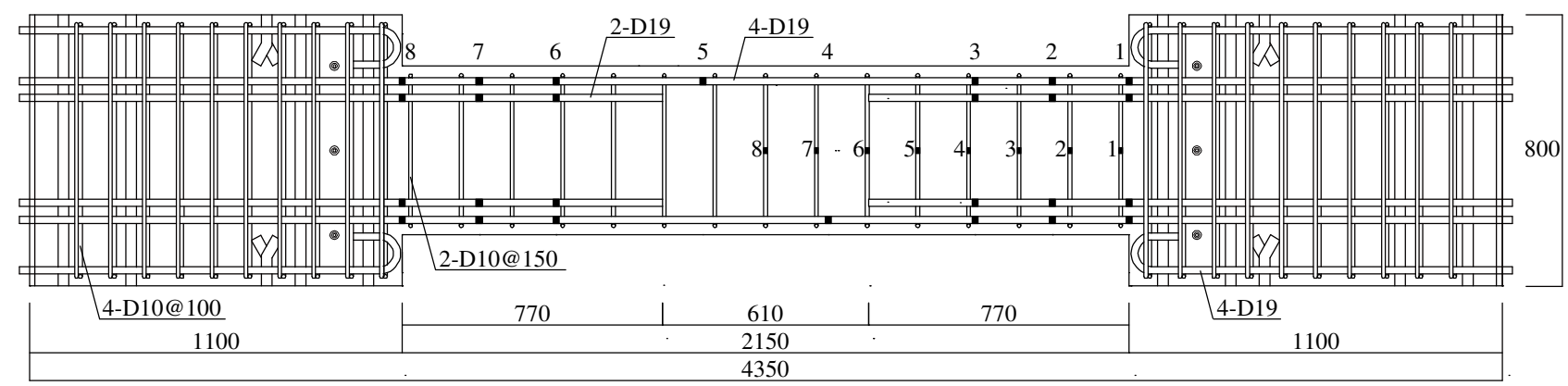

(a) DB2.5-w03-CL

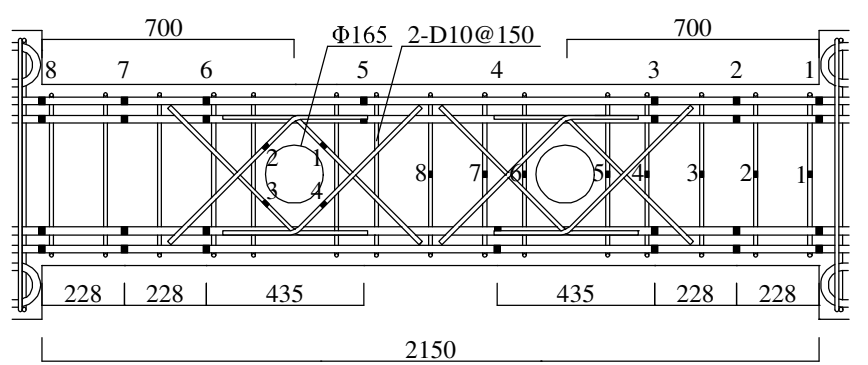

(b) DBO2.5-w09

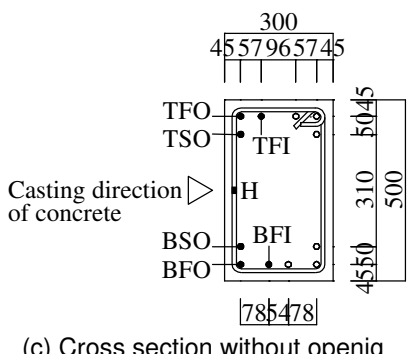

(c) Cross section without openig

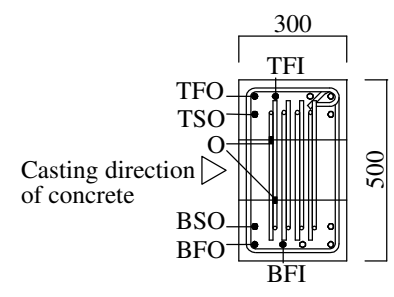

(d) Cross section with opening
Casting direction of concrete

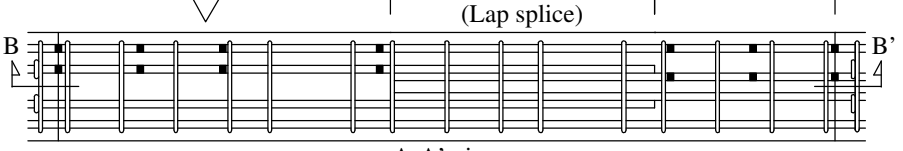

A-A' view

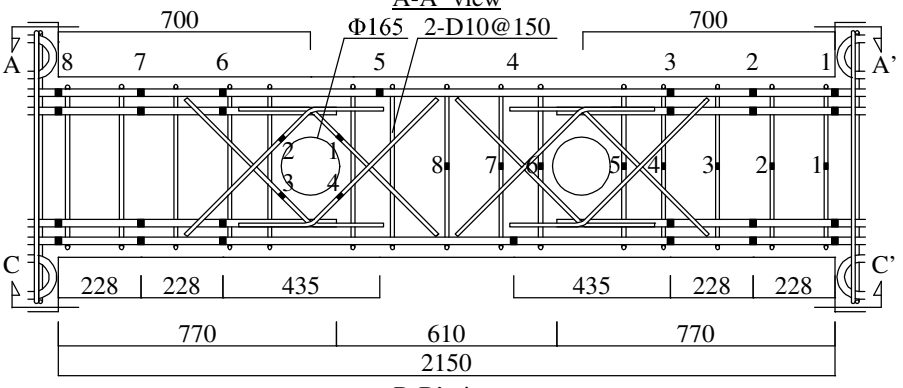

B-B' view

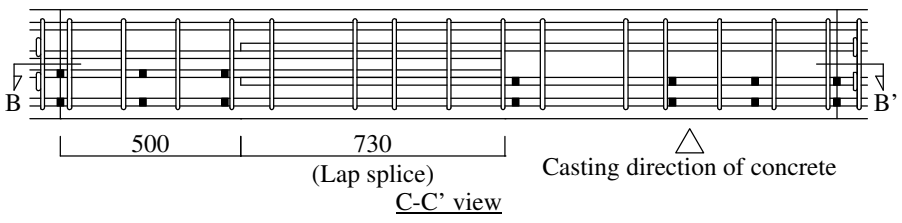

(e) DBO2.5-w09-CL

Fig.1 Dimension of specimen 
Table4 Calculations of structural performance

\begin{tabular}{|c|c|c|c|c|c|c|c|c|c|c|c|c|c|c|c|}
\hline & \multicolumn{6}{|c|}{ Allowable shear capacity } & \multirow{2}{*}{\multicolumn{4}{|c|}{$\begin{array}{c}\text { Required lap splice length } \\
\text { (ratio to requirement) } \\
l_{a b}[\mathrm{~mm}] \\
\left(l / l_{a b}\right) \\
\end{array}$}} & \multicolumn{2}{|c|}{$\begin{array}{l}\text { Ultimate shear capacity } \\
\text { (ratio to flexural capacity) }\end{array}$} & \multirow{3}{*}{\multicolumn{2}{|c|}{$\begin{array}{c}\begin{array}{c}\text { Bond strength } \\
\text { (ratio to requirement) }\end{array} \\
K f_{b}[\mathrm{Mpa}] \\
\left(K f_{b} / \tau_{D}\right)\end{array}$}} & \multirow{4}{*}{$\begin{array}{c}\begin{array}{c}\text { Required lap slice length } \\
\text { (ratio to requirement) }\end{array} \\
l_{a b}[\mathrm{~mm}] \\
\left(l / l_{a b}\right) \\
\text { for Safety }\end{array}$} \\
\hline & \multicolumn{2}{|c|}{ No opening region } & \multicolumn{4}{|c|}{ Region with opening } & & & & & \multirow{3}{*}{$\begin{array}{c}\begin{array}{c}\text { No opening } \\
\text { region }\end{array} \\
Q_{s u}[\mathrm{kN}] \\
\left(Q_{s u} / Q_{y}\right)\end{array}$} & \multirow{3}{*}{\begin{tabular}{|c|}
$\begin{array}{c}\text { region with } \\
\text { opening }\end{array}$ \\
$Q_{s u 0}[\mathrm{kN}]$ \\
$\left(Q_{s u} d Q_{y}\right)$
\end{tabular}} & & & \\
\hline & \multirow{2}{*}{$\begin{array}{l}Q_{A L} \\
{[\mathrm{kN}]}\end{array}$} & \multirow{2}{*}{$\begin{array}{c}Q_{A S} \\
{[\mathrm{kN}]}\end{array}$} & \multirow{2}{*}{$\begin{array}{c}Q_{A L 161} \\
{[\mathrm{kN}]}\end{array}$} & \multirow{2}{*}{$\begin{array}{l}Q_{A L 0} \\
{[\mathrm{kN}]}\end{array}$} & \multirow{2}{*}{$\begin{array}{c}Q_{A S 161} \\
{[\mathrm{kN}]}\end{array}$} & \multirow{2}{*}{$\begin{array}{l}Q_{A S 0} \\
{[\mathrm{kN}]}\end{array}$} & \multicolumn{2}{|c|}{ Long-term } & \multicolumn{2}{|c|}{\begin{tabular}{|l|} 
Short-term \\
\end{tabular}} & & & & & \\
\hline & & & & & & & Top bar & Other bar & Top bar & Other bar & & & 1 st bar & 2nd bar & \\
\hline DB2.5-w03-CL & 124 & 130 & - & - & - & - & \begin{tabular}{|c|}
566 \\
$(1.29)$ \\
\end{tabular} & \begin{tabular}{|c|}
378 \\
$(1.93)$ \\
\end{tabular} & \begin{tabular}{|c|}
606 \\
$(1.20)$ \\
\end{tabular} & \begin{tabular}{|c|}
404 \\
$(1.81)$ \\
\end{tabular} & $\begin{array}{c}235 \\
(1.04) \\
\end{array}$ & 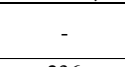 & $\begin{array}{c}2.77 \\
(1.10) \\
\end{array}$ & $\begin{array}{c}2.62 \\
(0.68) \\
\end{array}$ & $\begin{array}{c}677 \\
(1.08)\end{array}$ \\
\hline DBO2.5-w09 & 122 & 129 & 96 & 118 & 168 & 190 & 法 & 120, & (12.00 & 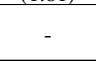 & $\begin{array}{c}232 \\
(1.03)\end{array}$ & $\begin{array}{c}236 \\
(1.05)\end{array}$ & $\begin{array}{c}2.72 \\
(1.37)\end{array}$ & $\begin{array}{c}2.58 \\
(1.73)\end{array}$ & $(1.00)$ \\
\hline DBO2.5-w09-CL & 123 & 130 & 96 & 119 & 168 & 190 & $\begin{array}{c}569 \\
(1.28) \\
\end{array}$ & $\begin{array}{c}380 \\
(1.92)\end{array}$ & $\begin{array}{c}609 \\
(1.20)\end{array}$ & $\begin{array}{c}406 \\
(1.80)\end{array}$ & $\begin{array}{c}234 \\
(1.04)\end{array}$ & $\begin{array}{c}237 \\
(1.05)\end{array}$ & $\begin{array}{c}2.75 \\
(1.10)\end{array}$ & $\begin{array}{c}2.61 \\
(0.68)\end{array}$ & $\begin{array}{c}680 \\
(1.07) \\
\end{array}$ \\
\hline
\end{tabular}

Table5 Plan of turning back point in cyclic loading

\begin{tabular}{|c|c|c|c|c|c|c|c|c|c|c|c|c|c|c|c|}
\hline Number of Cycle & \pm 1 & +2 & +3 & +4 & \pm 5 & +6 & \pm 7 & +8 & \pm 9 & +10 & \pm 11 & \pm 12 & \pm 13 & \pm 14 & +15 \\
\hline Shear load, $Q$ & $\pm 10 \mathrm{kN}$ & $+Q_{A L 161}$ & $+Q_{A L 0}$ & $+Q_{A L}$ & $\pm Q_{A S}$ & $+Q_{A S}$ & $\pm Q_{A S 161}$ & $+Q_{A S 161}$ & $\pm Q_{A S 0}$ & $+Q_{A S 0}$ & - & - & - & - & - \\
\hline Deformation angle, $R$ & - & - & - & - & - & - & - & - & - & - & $\pm 1.0 \%$ & $\pm 1.0 \%$ & $\pm 2.0 \%$ & $\pm 2.0 \%$ & $+3.0 \%$ \\
\hline
\end{tabular}

2.5 : せん断スパン比, w03(w09)= web 03\%(web 09\%o) : 横補強筋比 （孔周囲の補強筋比）, CL =Cut-off, Lap splice : カットオフ, 重㸚継 手の有無を表す。Fig.1(a)に示すように，DB2.5-w03-CL（Table1 の No.1) は DBO2.5-w09-CL から貫通孔をなくした試験体, DBO2.5-w09

（Table1 の No.2）は DBO2.5-w09-CL から主筋を 2 段とも継手の無 い通し筋とした試験体である。

Fig.2 に加力装置図を示す。試験体の右側スタブ（南側スタブ）を 固定し, 左右のスタブを平行に維持しながら左側のスタブを上下に 変位させた。載荷は $500 \mathrm{kN}, 1000 \mathrm{kN}$ の 2 本の油圧ジャッキを載荷 梁に取り付け，左側スタブ（北側スタブ）の上方向の変位を正側と して, 逆対称曲げモーメントを加える正負繰り返し載荷とした。

\section{2 構造特性および加力計画}

Table4 に試験体の構造特性を示す。耐力計算に用いた材料強度は, コンクリートには加力前のシリンダー試験值, 鉄筋は, 許容耐力に は長期もしくは短期許容応力度, 終局耐力には降伏強度の試験值を 用いた。長期と短期の許容せん断力, 付着割裂強度 $K f_{b}$, 安全性検討 用の付着応力度 $\tau_{D}$ は $\mathrm{RC}$ 規準 ${ }^{1}$ により計算した。 $l$ は重称継手長さ, $l_{a b}$ は必要重衫継手長さであり, RC 規準の使用性, 損傷制御性, 安 全性の確保のための検定式を使用した。なお，使用性と損傷制御性 の $l_{a b}$ は, 継手位置に関わらず上端筋の許容付着応力度を使用するこ とになっているが，試験体はその他の鉄筋に該当するため, Table4 には参考としてその他の鉄筋の許容付着応力度を用いた $l_{a b}$ も示し ている。曲げ降伏モーメントには略算式 1)を用い, 曲げ降伏時のせ ん断力を $Q_{y}$ とした。梁の無孔部の終局せん断耐力 $Q_{s u}$ は荒川 $\min$ 式 を用い，梁の有孔部の終局せん断力 $Q_{s u 0}$ は $\mathrm{RC}$ 規準 ${ }^{1)}$ を用いて算出 した。いずれの試験体もせん断余裕度 $Q_{s u} / Q_{y}$ と $Q_{s u} / Q_{y}$ をほぼ 1 にし た。計算上の破壊モードは, DB2.5-w03-CL と DBO2.5-w09-CL は 2 段目主筋の付着破壊であり, DBO2.5-w09 は曲げ降伏後のせん断破 壊が想定される。なお， Table4 の $Q_{A L 161}$ と $Q_{A S 161}$ は，長期許容せん 断力 $Q_{A L 0}$, 短期許容せん断力 $Q_{A S 0}$ の開孔低減率 1.00 を, 終局せん断 耐力 $Q_{s u 0}$ と同じ 1.61 にしたものである。

Table5 に加力計画を示す。まず, 計測機器の動作確認のため正負 加力とも $10 \mathrm{kN}$ ずつ加力し, これを 1 cycle とした。それ以降から $4 \mathrm{cycle}$ までは長期許容せん断力 $Q_{A L 161}$ (有孔部, 開孔低減率変更), $Q_{A L 0}$ (有孔部), $Q_{A L}$ (無孔部, せん断ひび割れ許容), その後, $10 \mathrm{cycle}$

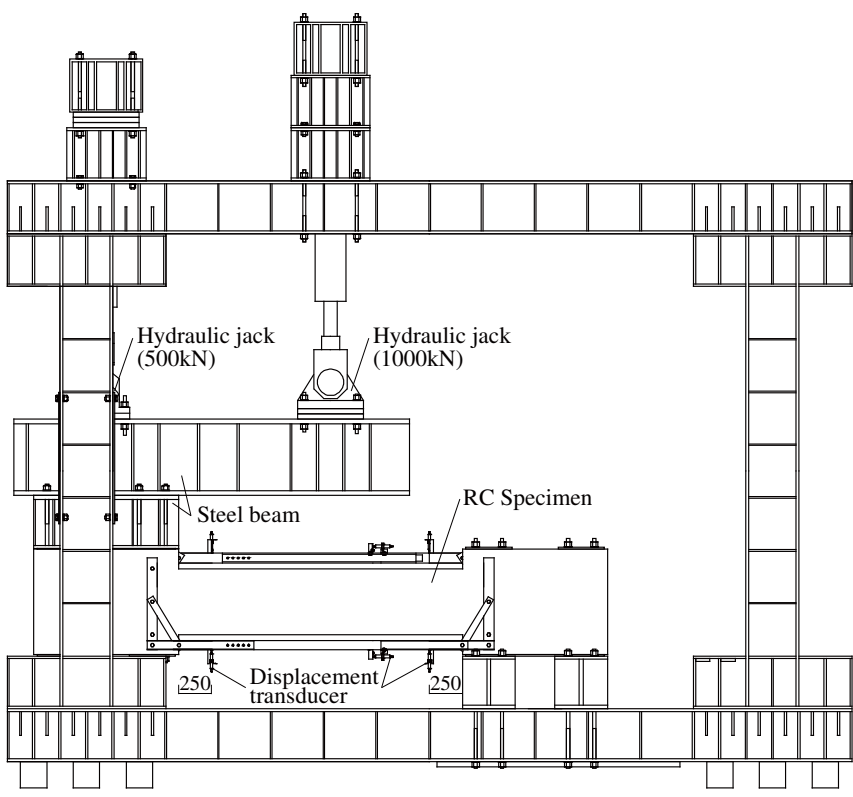

Fig.2 Loading setup and measuring system

までは短期許容せん断力 $Q_{A S}$ (無孔部), $Q_{A S 161}$ (有孔部, 開孔低減率変 更), $Q_{A S 0}$ (有孔部)を目標とした荷重制御とした。11cycle 以降は部材 角 $R=1.0 \% ， 2.0 \% ， 3.0 \%$ となるように変位制御で加力した。

\section{3. 実験結果}

\section{1 せん断カー部材角関係}

Fig.3 に DB2.5-w03-CL，DBO2.5-w0.9，DBO2.5-w09-CL のせん断 力 $Q$-部材角 $R$ 関係（以下， $Q-R$ 関係）を示寸。せん断力は, 試験 体へ加力した 2 本の油圧ジャッキの荷重の和である。部材角は, 梁 端部から $250 \mathrm{~mm}$ 離れた 4 箇所に設置した変位計により回転角を測 定し，それらの平均値とした。Fig.3 には試験体の耐力算定値（ $Q_{s u}$, $\left.Q_{s u 0}, Q_{y}\right)$ を併せて示している。いずれの試験体も荷重は曲げ耐力, 無孔部のせん断耐力, 有孔部のせん断耐力を上回った。最大耐力, 主筋初降伏時の荷重と部材角を Table6 に示す。 $R=+2.0 \%$ (1 回目) までは 3 体とも同じような $Q-R$ 関係となったものの, $R=-2.0 \%$ (1 回 目）から違いが生じており，DB2.5-w03-CL は他の 2 体と比べると 早期に耐力が低下した。この要因としては, 貫通孔を有する DBO2.5- 
w09, DBO2.5-w09-CL には孔周囲補強筋が存在し, この定着部がせ ん断に抵抗したためこのような違いが生じたものと考えられ, 詳細 は後述する。また, 最大耐力時の部材角は, カットオフ筋の無い DBO2.5-w09 は+1.0\%時であったが，カットオフ筋を有する DB2.5w03-CL, DBO2.5-w09-CL では+2.0\%時で, カットオフ筋のすべり変 位により，DBO2.5-w09 に比べて部材角が大きくなったものと考え られる。鉄筋の降伏状況は，主筋初降伏は 1 段目鉄筋， 2 段目鉄筋 ともに正側負側において全ての試験体で同程度の部材角で生じて いる。

Table6 Load and deformation angle at events

\begin{tabular}{c|c|c|c|c}
\hline \multicolumn{2}{l|}{} & DB2.5-w03-CL & DBO2.5-w09 & DBO2.5-w09-CL \\
\hline $\begin{array}{c}\text { Initial yielding in outer (1st) bar } \\
\text { (positive direction) }\end{array}$ & $Q[\mathrm{kN}]$ & 216 & 238 & 219 \\
\cline { 2 - 5 } & $R[\%]$ & 0.48 & 0.52 & 0.49 \\
\hline $\begin{array}{c}\text { Initial yielding in outer (1st) bar } \\
\text { (negative direction) }\end{array}$ & $Q[\mathrm{kN}]$ & -202 & -188 & -212 \\
\cline { 2 - 5 } & $R[\%]$ & -0.39 & -0.22 & -0.32 \\
\hline $\begin{array}{c}\text { Initial yielding in inner (2nd) bar } \\
\text { (positive direction) }\end{array}$ & $Q[\mathrm{kN}]$ & 259 & 251 & 251 \\
\cline { 2 - 5 } & $R[\%]$ & 0.77 & 0.60 & 0.65 \\
\hline $\begin{array}{c}\text { Initial yielding in inner (2nd) bar } \\
\text { (negative direction) }\end{array}$ & $Q[\mathrm{kN}]$ & -230 & -221 & -233 \\
\cline { 2 - 5 } & $R[\%]$ & -0.64 & -0.44 & -0.47 \\
\hline \multirow{2}{\text{Maximumload}}{$\begin{array}{c}\text { (positive direction) } \\
\text { Maximum load }\end{array}$} & $Q[\mathrm{kN}]$ & 266 & 263 & 262 \\
\cline { 2 - 5 } (negative direction) & $R[\%]$ & 2.01 & 1.03 & 2.01 \\
\hline & $Q[\mathrm{kN}]$ & -242 & -239 & -248 \\
\hline
\end{tabular}

\section{2 ひび割れおよび損傷の様子}

Fig.4 に部材角 $R=+1.0 \%$ 時のひび割れ図, Fig.5 に最終破壊写真, Table7 に各初期ひび割れ発生時の荷重と部材角を示す。ひび割れは, 各 cycle のピーク時と除荷時（荷重ゼロ）に観測した。Fig.4 に示す ひび割れ図は打設面ではない西面におけるもので，図内の黒三角印 は後述する残留せん断ひび割れ幅が最大となった計測箇所を表し ている。実線が正加力時のひび割れ，点線が負加力時のひび割れを

Table7 Load and deformation angle at initial cracks

\begin{tabular}{c|c|c|c|c|c|c}
\hline \multirow{2}{*}{ Specimen } & \multicolumn{2}{|c|}{ Bending crack } & \multicolumn{4}{c}{ Shear crack } \\
\cline { 2 - 7 } & $\begin{array}{c}\text { Shear load } \\
{[\mathrm{kN}]}\end{array}$ & $\begin{array}{c}\text { Deformation } \\
\text { angle [\%] }\end{array}$ & $\begin{array}{c}\text { Shear load } \\
{[\mathrm{kN}]}\end{array}$ & $\begin{array}{c}\text { Deformation } \\
\text { angle }[\%]\end{array}$ & $\begin{array}{c}\text { Shear load } \\
{[\mathrm{kN}]}\end{array}$ & $\begin{array}{c}\text { Deformation } \\
\text { angle [\%] }\end{array}$ \\
\hline DB2.5-w03-CL & 58 & 0.04 & - & - & 120 & 0.18 \\
\hline DBO2.5-w09 & 74 & 0.07 & 114 & 0.17 & 97 & 0.12 \\
\hline DBO2.5-w09-CL & 66 & 0.06 & 109 & 0.18 & 109 & 0.18 \\
\hline
\end{tabular}

Table8 Tensile stress in reinforcement around opening at $R=+1.0 \%$ (First cycle), $+2.0 \%$ (First cycle)

\begin{tabular}{c|c|c|c|c|c|c|c|c}
\hline & \multicolumn{6}{|c}{ Tensile stress in reinforcement around opening [MPa] } \\
\cline { 2 - 10 } & \multicolumn{4}{|c|}{ DBO2.5-w09 } & \multicolumn{4}{c}{ DBO2.5-w09-CL } \\
\cline { 2 - 9 } & O1 & O2 & O3 & O4 & O1 & O2 & O3 & O4 \\
\hline $1 \%$ (First cycle) & 280 & -18 & 274 & -58 & 224 & -4 & 310 & -55 \\
\hline $2 \%$ (First cycle) & 288 & -23 & 274 & -45 & 188 & -8 & 296 & -40 \\
\hline
\end{tabular}

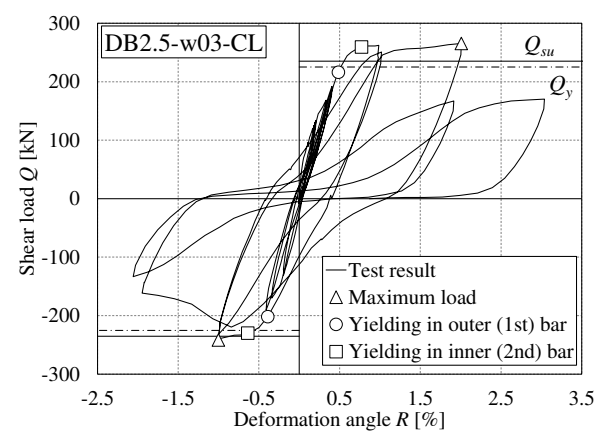

(a) DB2.5-w03-CL

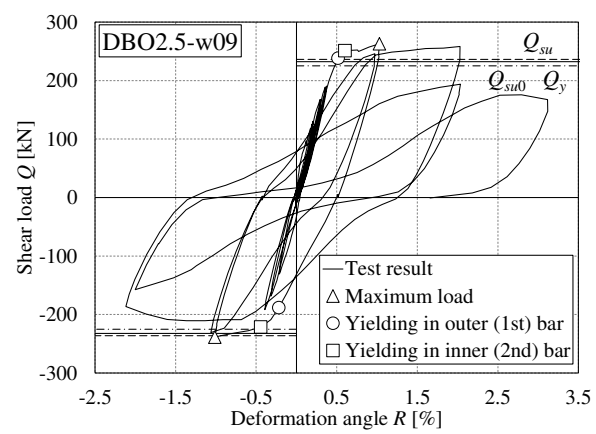

(b) DBO2.5-w09

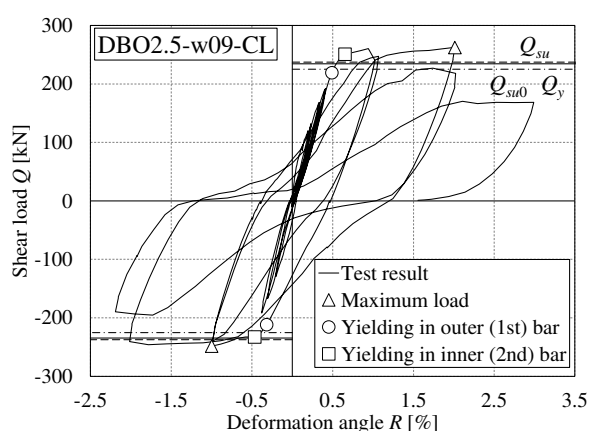

(c) DBO2.5-w09-CL

Fig.3 Shear load-deformation angle at a cycle peak

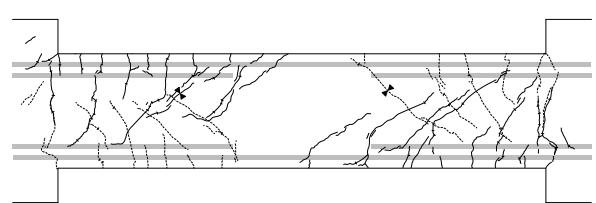

(a) DB2.5-w03-CL

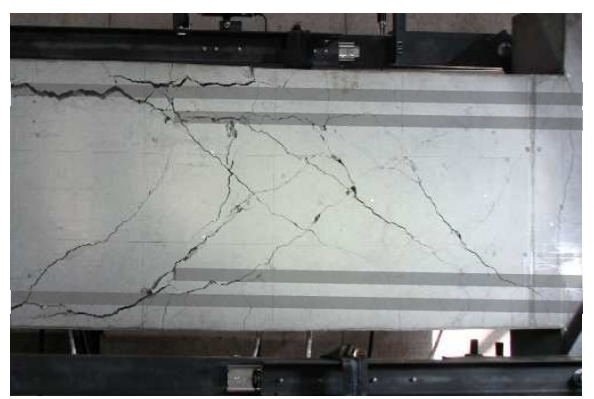

(a) DB2.5-w03-CL

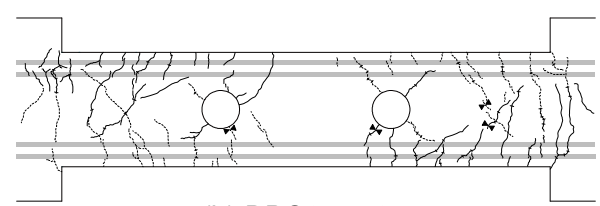

(b) DBO2.5-w09

Fig.4 Observed cracks at $R=+1.0 \%$ (First cycle)

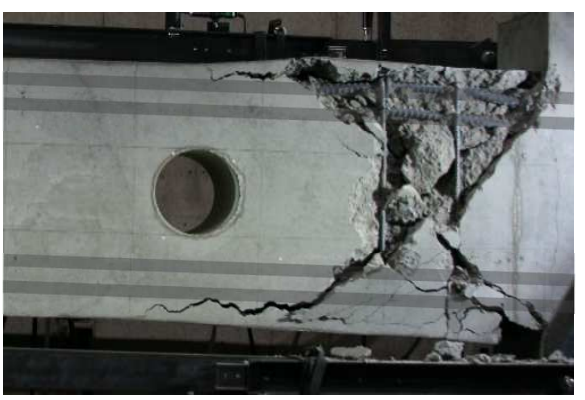

(b) DBO2.5-w09

Fig.5 Photo of specimens after failure

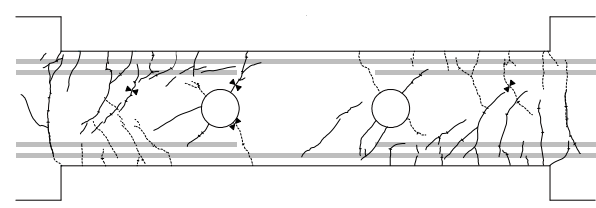

(c) DBO2.5-w09-CL

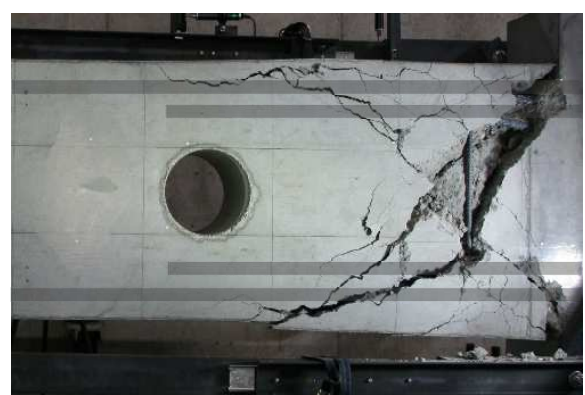

(c) DBO2.5-w09-CL 
表している。打設面では, 加力前のひび割れと加力によるひび割れ の区別が難しいため, Table7 に示す各初期ひび割れ発生時の荷重と 部材角は打設面ではない西面における観測結果である。貫通孔を有 する DBO2.5-w09 と DBO2.5-w09-CL を比較すると, 初期曲げひび 割れと初期せん断ひび割れの発生荷重にほとんど差はない。一方, 貫通孔の無い DB2.5-w03-CL では, 他の 2 体と比較して, 初期せん 断ひび割れ発生荷重が他の 2 体よりも大きく, 貫通孔の影響が見ら れた。

Fig.5 の最終破壊写真より貫通孔の無いDB2.5-w03-CL では梁端部 から 700mm 程度の位置（他の試験体では貫通孔のある位置）までせ ん断ひび割れが見られるが, 貫通孔を有する DBO2.5-w09, DBO2.5w09-CL は梁端部に集中している。Table8 に部材角 $R=+1.0 \%$ (1 回 目）， $+2.0 \%$ （1 回目）時の孔周囲補強筋の応力度を示寸。 DBO2.5w09, DBO2.5-w09-CL のいずれの孔周囲補強筋の応力度も降伏強度 を下回っており, 孔周囲補強筋は弾性範囲に収まった。このように 貫通孔周囲の応力度が大きくないため貫通孔周囲のひび割れ幅は あまり広がらなかったと考えられる。また, Fig.5 では, DB2.5-w03CL は梁スパン中央部に付着ひび割れが見られるが，DBO2.5-w09， DBO2.5-w09-CL にはこのような付着ひび割れは見られなかった。

\section{3 許容せん断カとひび割れ幅}

許容せん断力時のせん断ひび割れ幅を確認し, RC 規準 ${ }^{1)}$ 記載の貫 通孔を有する梁の短期許容せん断力と残留ひび割れ幅との関係を 検証する。 $\mathrm{RC}$ 規準 ${ }^{1)}$ では損傷制御のための短期許容せん断力は, 建 築物の外面で $0.2 \mathrm{~mm} \sim 0.25 \mathrm{~mm}$, 内面で $0.3 \mathrm{~mm} \sim 0.4 \mathrm{~mm}$ 程度の残留 ひび割れにとどまるレベルとされている。縮小試験体を用いた過去 の研究では ${ }^{11)}, 1 / 2$ スケール試験体の残留最大ひび割れ幅, および ひび割れ幅の合計は, 実大スケール試験体に比べ, 最大ひび割れ幅 で $0.6 \sim 0.7$ 倍，ひび割れ幅の合計で 0.5 倍程度と報告されている。

Fig.6 に各試験体のサイクル除荷時（荷重ゼロ）における各最大残 留ひび割れ幅の推移を示す。縦軸はひび割れ幅 $[\mathrm{mm}]$, 横軸は除荷時 のサイクル数である。最大残留ひび割れは, +5 cycle から+10cycle ま でに最大残留ひび割れ幅を持つひび割れとし, 最大残留ひび割れ幅 が同じひび割れが複数存在する場合は，+10cycle 除荷時により大き いひび割れ幅のものとした。Fig.4に黒三角印でひび割れ幅計測位置 を示している。ひび割れ幅はクラックスケールを用いて測定した。 図内の一点鎖線は, RC 規準 ${ }^{1)}$ の短期許容せん断力レベルで想定して いる残留せん断ひび割れ幅を表している。本試験体スケールはおよ そ $1 / 2$ のため, 既往の研究 ${ }^{11}$ より安全側に評価し， $0.2 \mathrm{~mm}$ を $1 / 2$ 倍 した $0.1 \mathrm{~mm}$ とした。Table5 に示すように, +10cycle ピーク時の載荷 荷重までが有孔部許容せん断力であり，+10cycle までのひび割れ幅 を確認する必要がある。Fig.6 を確認すると，無孔部の短期許容せん 断力の 6cycle までは, 孔際では残留ひび割れが生じているものの(丸 印），無孔部ではひび割れはほとんど閉じている（三角印）。それ 以降は，無孔部の残留ひび割れは $0.1 \mathrm{~mm}$ を超えたものがあったが， 孔際では 0.1 $\mathrm{mm}$ 以内に収まっている。DBO2.5-w09 では，東面の有 孔部におけるせん断ひび割れ幅が+5cycle 除荷時に $0.15 \mathrm{~mm}$ となって おり， $0.1 \mathrm{~mm}$ を超過している。しかし， -5cycle 以降の除荷時はひ び割れ幅が $0.1 \mathrm{~mm}$ 以下となっていることを考慮すると, DBO2.5-w09 に関しても想定内の残留ひび割れ幅と考えることができる。

\section{4. 考察}

\section{1 梁主筋の付着応力度}

Fig.5 の最終破壞写真に示したように, 貫通孔の有無によって破壊 位置が異なった。ここでは, 主筋応力度分布図を比較する。

Fig. 7 に部材角 $R=+1.0 \%$ 時における主筋の応力度分布図を示す。上 段図は配筋，下段図は応力度分布を示している。上段に示寸配筋図 は，上が上端の配筋図，下が下端の配筋図を示寸。下段に示寸応力 度分布図は, 縦軸が応力度, 横軸が梁右端からの距離を示している。 応力度分布上部に記載の数字は断面位置（1～8）を意味し, Fig.1の 試験体図に対応している。ひずみ度から応力度への換算では, 2500 $\mu$ までを完全弾塑性, その後は最大経験ひずみを超えた時に降伏強 度として換算し, それ以外は応力度に換算していない。丸及び四角 印が実験結果である。 $\mathrm{RC}$ 規準 ${ }^{1)}$ の付着割裂強度による 1 段筋と 2 段 筋の応力度分布の計算値を破線で示している。主筋の付着応力度か ら軸応力度への換算は次式の関係を用いている。

$$
\frac{\Delta \sigma}{l_{m}}=\frac{4 \tau_{b}}{d_{b}}
$$

式(1)の左辺は軸応力度の勾配で, $\Delta \sigma$ は主筋の 2 点間の応力度差, 2 点間の長さを $l_{m}$ としている。この 2 点間の平均付着応力度を $\tau_{b}$ とす れば， $\tau_{b}=\Delta \sigma d_{b} /\left(4 l_{m}\right)$ なので式(1)を得る。ここで, $d_{b}$ は鉄筋径で, 本 論文では異形鉄筋の呼びの值を用いる。式(1)の $\tau_{b}$ に付着割裂強度の

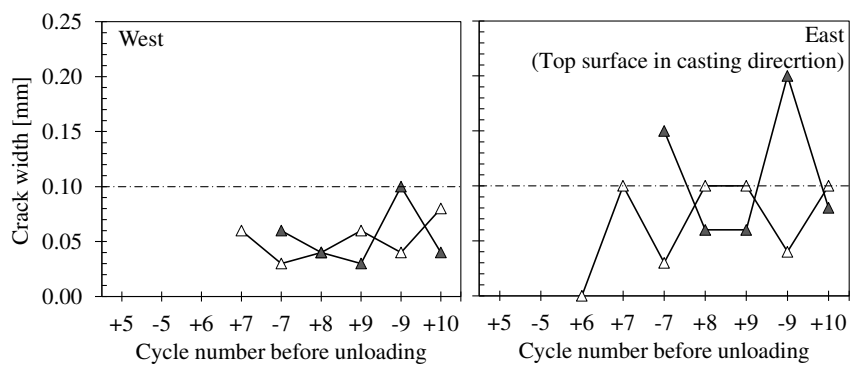

(a) DB2.5-w03-CL

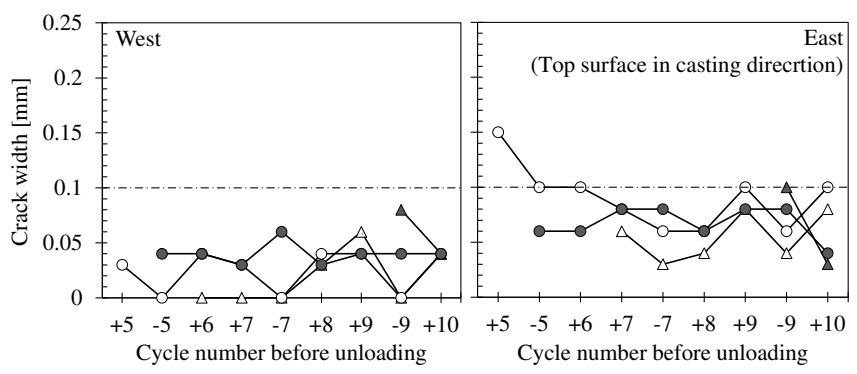

(b) DBO2.5-w09

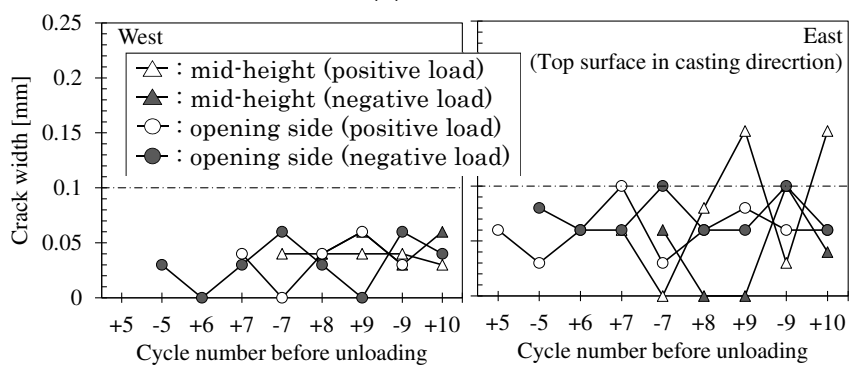

(c) DBO2.5-w09-CL

Fig.6 Residual width of shear crack 
計算值を代入すれば, Fig.7 の主筋応力度分布図における線分の傾き が得られる。Fig.7 において，2段目カットオフ筋の破線は, カット オフ位置から付着割裂強度から得られる傾きで描かれており, 降伏 強度で一定 (水平) としている。通し筋の破線は, テンションシフ トの範囲では降伏強度で一定值, それを超えると付着割裂強度から 得られる傾きで描かれており, 圧縮降伏強度で再び一定（水平）と している。テンションシフトの範囲は Fig.7 の応力度分布図の上部 に示しており, $\mathrm{RC}$ 規準 ${ }^{1}$ に従って, 2 段目が通し筋の場合は有効せ い $d$, カットオフ筋の場合は $d+l$ ' $(l$ 'はカットオフ筋が計算上不要と なる断面）としている。なお， 2 段筋の付着割裂強度は, RC 規準 ${ }^{1)}$ の解説に従い, 0.6 倍でなく, 0.8 倍に低減した值である。

カットオフ筋を有する DB2.5-w03-CL, DBO2.5-w09-CL を比較し て最も大きな違いは, 貫通孔を有する DBO2.5-w09-CL の 1 段筋の 付着応力度は, DB2.5-w03-CL に比べて, 下端の 3-4 区間では大き く, 4-6 区間では小さいことである。上端の 6-5 区間と 5-3 区間も同 様である。既往の研究 ${ }^{12}$ や RC 規準 ${ }^{1)}$ の解説でも述べられているよ うに， 2 段とも通し筋の場合， 1 段目と 2 段目のテンションシフト の範囲や付着応力は同程度となるが, 2 段目鉄筋をカットオフした 場合, 付着応力は 2 段目鉄筋では高くなって 1 段目鉄筋では低くな る（Fig.7(a)の 3-4 区間と 6-5 区間）。この現象は， 2 段配筋の付着 応力の総和が 2 段目鉄筋のカットオフの有無にあまり影響されない, という考え方で説明されている ${ }^{1}$ 。つまり，2段目カットオフ筋の付 着応力が高くなった分, その区間での 1 段目通し筋の付着応力が低 くなり, 1 段目鉄筋のテンションシフトの範囲は拡がる。その結果, 1 段目通し筋に必要な付着力がカットオフ筋の無い区間（Fig.7(a)の 4-6 区間と 5-3 区間) で伝達されるため, その区間の付着応力が高く なると考えられている。DBO2.5-w09-CL (Fig.7(c)) の 1 段目通し筋 の主筋軸応力度分布は， 2 段とも通し筋の DBO2.5-w09（Fig.7(b)） の 1 段目通し筋のそれに近い。これは, DBO2.5-w09-CLの 3-4 区間 と 6-5 区間には孔周囲補強筋の余長部があり，2 段目カットオフ筋 との間で重ね継手のような応力伝達がなされ，3-4 区間と 6-5 区間 において 2 段目鉄筋が通し筋のような状態になったためと考えられ る。また, 2 段目カットオフ筋の付着応力度は付着割裂強度計算值 と同程度で, 滑り変位は大きい状態と考えられ, 2 段とも通し筋の DBO2.5-w09 よりも最大耐力時の部材角が大きくなったものと考え られる。

\section{2 破壊要因}

Fig.8，9，10 には, DB2.5-w03-CL, DBO2.5-w09, DBO2.5-w09-CL
の主筋付着応力度一部材角関係と横補強筋ひずみ度一部材角関係 をそれぞれ示しており，それぞれ引張応力度，引張ひずみ度を正と している。ここに示す主筋付着応力度及び横補強筋ひずみ度は, DB2.5-w03-CL，DBO2.5-w09 で耐力低下を生じた-13cycle における ものである。Fig.11 に付着応力度計測位置を示す。Fig.11(a)は DBO2.5-w09, (b)はDBO2.5-w09-CLにおけるもので, DB2.5-w03-CL は Fig.11(b)に示す計測位置と同様である。梁端部にある黒矢印は加 力方向を表している。Fig.8, 9, 10 内の記号 (TFO, TFI 等) は, Fig.11 内に示寸鉄筋位置に対応しており，付着応力度の算定区間は灰色で 塗られている。括弧内は付着応力度の算出に使用したひずみゲージ の断面番号を表しており, end は鉄筋端部のことで応力度を 0 とし て計算した。ここでは, 主筋付着応力度の低下と横補強筋ひずみ度 の急激な増大のどちらが先かを分析することで破壊要因を推察す る。

DB2.5-w03-CLについて, 1 段目引張鉄筋通し筋の付着応力度の低 下は部材角 $R=-0.69 \%$ 時で, 1 段目引張鉄筋継手部, 2 段目引張鉄筋 の付着応力度の低下及び横補強筋 $\mathrm{H} 3$ のひずみ度の増加は部材角 $R=-0.84 \%$ 時であり, わずかに 1 段目引張鉄筋通し筋の付着応力度の 低下が早い結果となった。DBO2.5-w09 について, 横補強筋 H2 のひ ずみ度の増加は部材角 $R=-0.68 \%$ 時で, 付着応力度の低下に比べ明ら かに早い結果となった。DBO2.5-w09-CL では, 主筋の付着応力度は いずれも低下しておらず, 4.1 節で述べたように, 孔周囲補強筋が付 着応力度を伝達したためと考えられる。横補強筋 $\mathrm{H} 2$ のひずみ度は 部材角 $R=-1.10 \%$ 以降は測定不能となった。最後に計測した部材角 $R=-1.10 \%$ 時のひずみは $1813 \mu$ と降伏時のひずみ度に近い值を取っ ている。また, Fig.5 の試験体写真を見てみると横補強筋 $\mathrm{H} 2$ 周辺に は大きなせん断ひび割れが存在し, これらのことから, 横補強筋 $\mathrm{H} 2$ のひずみ度は， $R=-1.10 \%$ 以降に急激に増加したことが推測できる。

以上より，それぞれの試験体の破壊要因は, DB2.5-w03-CL では付 着破壊, DBO2.5-w09, DBO2.5-w09-CL ではせん断破壊であり，これ は Fig.5 に示寸試験体写真と整合した破壊形式である。 DB2.5-w03CL，DBO2.5-w09-CL は，設計時には 2 段目カットオフ筋の付着余 裕度を低くし, 付着破壊を想定していたが, そのような破壊形式と ならなかったことから, カットオフ筋の付着余裕度はかなり安全側 と言える。DBO2.5-w09 は, 設計時の想定通りの破壊となったが, 無 孔部終局せん断余裕度が 1.03 , 有孔部終局せん断余裕度が 1.05 とほ ぼ同じであるにもかかわらず，孔周囲補強筋は降伏せずに無孔部で のせん断破壊となったことより, 有孔部の終局せん断耐力の余裕度
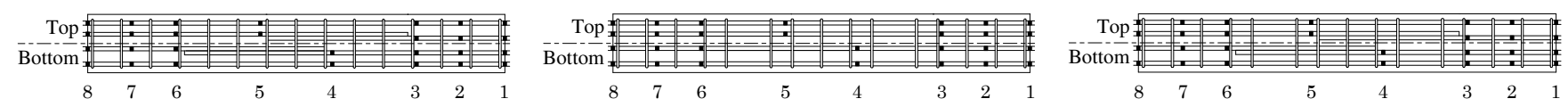

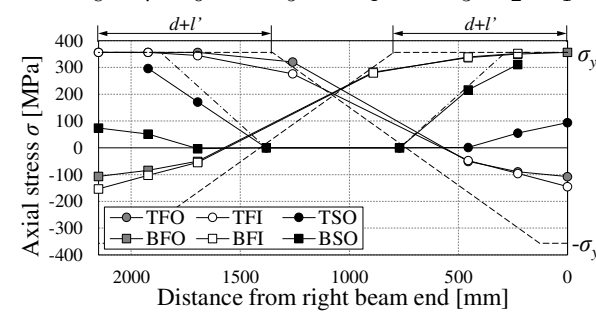

(a) DB2.5-w03-CL

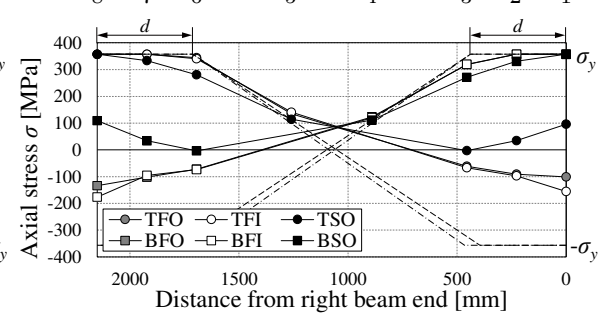

(b) DBO2.5-w09

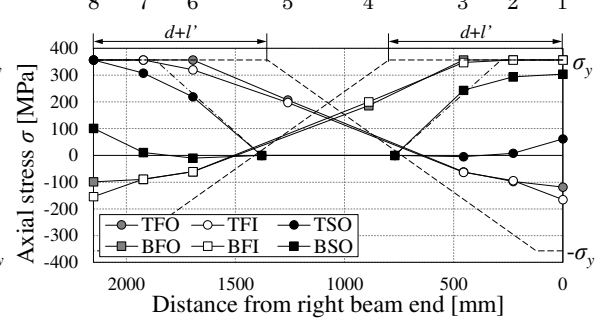

(c) DBO2.5-w09-CL

Fig.7 Axial stress in longitudinal bars at $R=+1.0 \%$ (First cycle) 


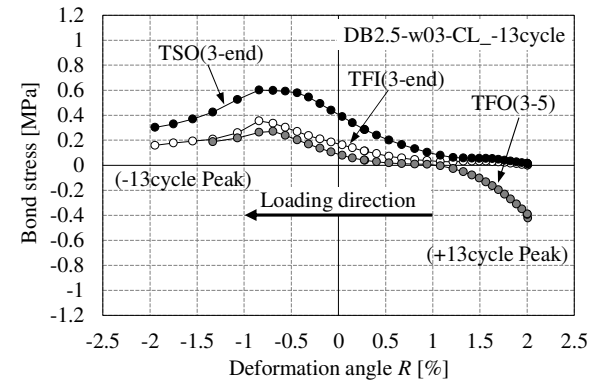

(a) Bond stress (top bars)

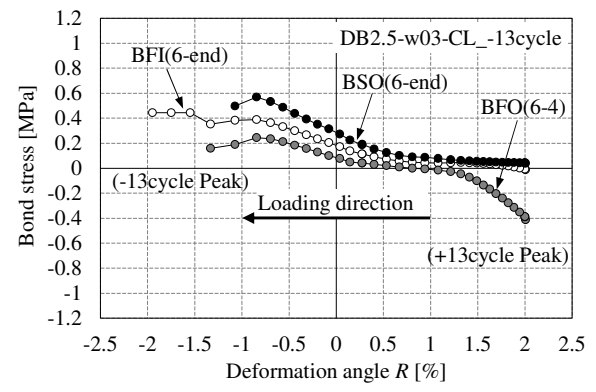

(b) Bond stress (bottom bars)

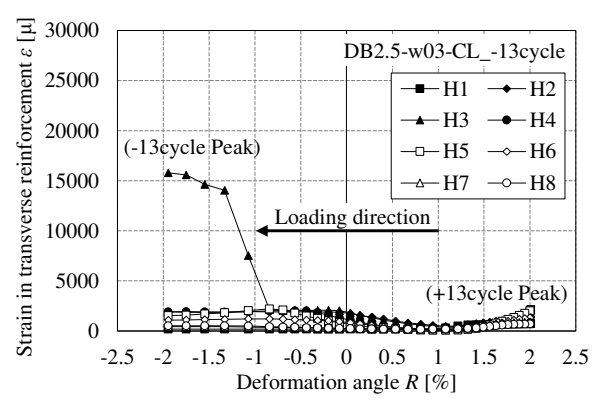

(c) Strain in transverse reinforcement

Fig.8 Changes of stress and strain to deformation angle; DB2.5-w03-CL

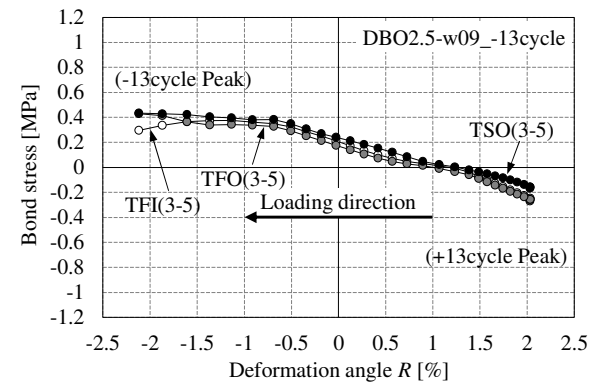

(a) Bond stress (top bars)

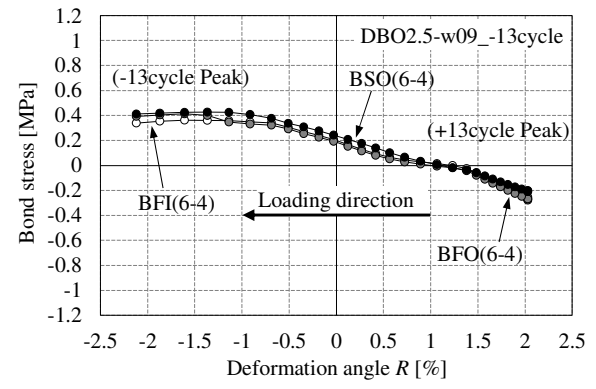

(b) Bond stress (bottom bars)

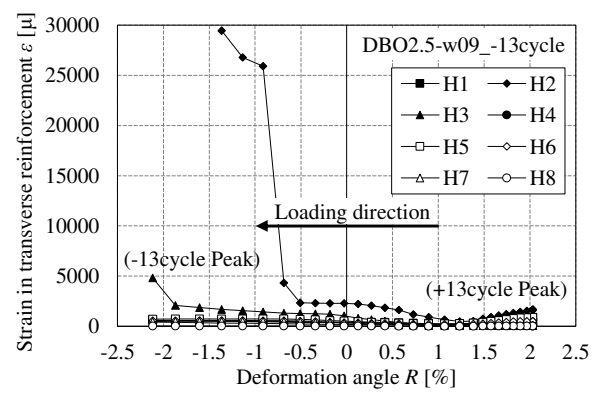

(c) Strain in transverse reinforcement

Fig. 9 Changes of stress and strain to deformation angle; DBO2.5-w09

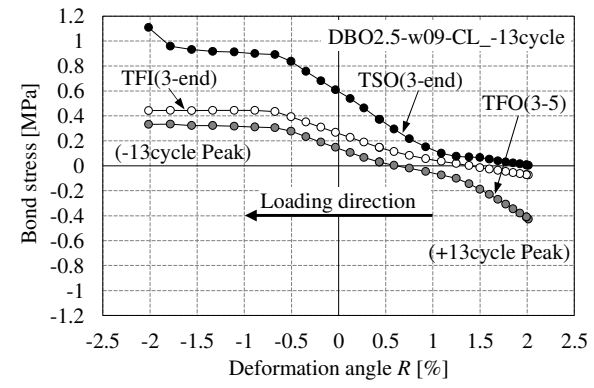

(a) Bond stress (top bars)

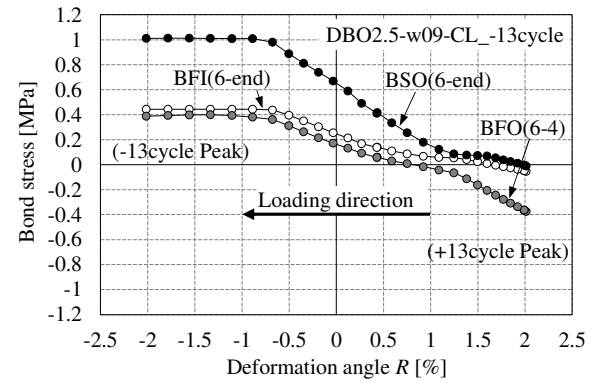

(b) Bond stress (bottom bars)

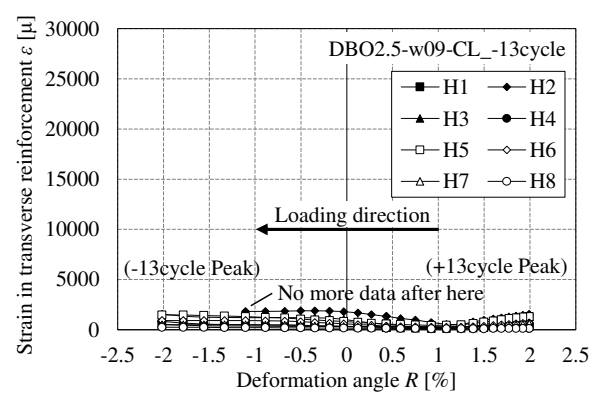

(c) Strain in transverse reinforcement

Fig.10 Changes of stress and strain to deformation angle; DBO2.5-w09-CL

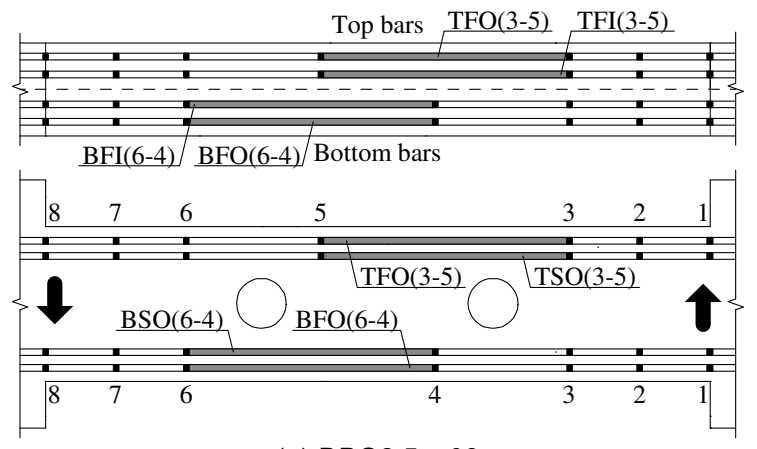

(a) DBO2.5-w09

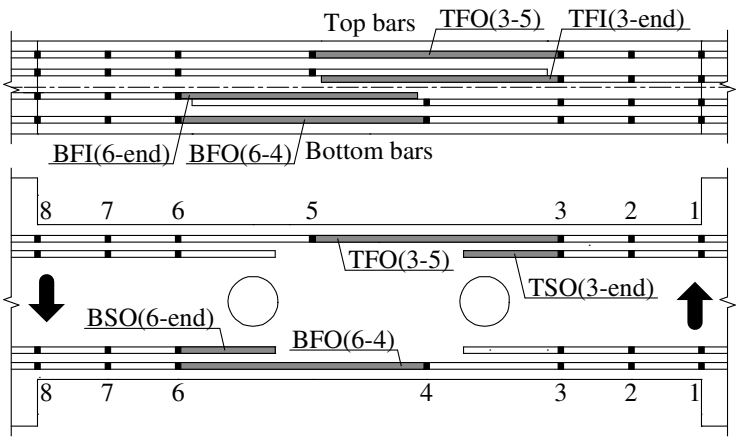

(b) DBO2.5-w09-CL

Fig.11 Section of steel bar for calculation

は無孔部に比べて安全側と考えられる。DB2.5-w03-CLにおいて, 1 段筋の付着余裕度と継手長さ余裕度は 1.1 前後で, 継手の余裕度の 方が若干小さいが, 継手の付着応力度の低下が先行することはなか ったため, 必要継手長さの余裕度は通し筋の付着余裕度よりもやや 安全側の評価と考えられる。また, 本実験では, 鉄筋のカットオフ
と重ね継手の影響を同時に受ける試験体を計画したが，貫通孔を有 する DBO2.5-w09-CL では最大耐力まで重ね継手に沿ったひび割れ も観測されず, 破壊形式もせん断破壊であったため, 重㸚継手の影 響は軽微だったと思われる。貫通孔の無い DB2.5-w03-CL では, 1 段 目の付着破壊で重ね継手に沿ったひび割れも観測されたため, 継手 
の影響は多少あったと思われるが, 継手の無い 1 段目隅主筋の付着 劣化がわずかに先行したため，その影響は限定的だったと考えられ る。

\section{3 横補強筋の引張応力度}

前述したように, ひずみ度が急激に増加した横補強筋の位置は, 孔周囲補強筋の有無（貫通孔の有無）によって異なっていた。Fig.12 は, $R=+1.0 \%$ （1 回目）, $+2.0 \%$ （1 回目）時における横補強筋の引 張応力度分布を示している。縦軸が引張応力度, 横軸が横補強筋の 位置で, 梁右端からの距離を示している。応力度は主筋と同様にひ ずみ度から換算した。四角印が各実験結果である。破線は, 横補強 筋の降伏強度である。Fig.12(a)はひずみゲージの㙋付位置を示して おり，上が DB2.5-w03-CL，下が DBO2.5-w09-CL である。Fig.12(b), (c)はピーク時の実験值だが, 例えば DB2.5-w03-CL の 500mm あた りに位置する横補強筋で降伏強度よりもやや低い值となっている のは，ピーク前に降伏したものの，ピーク時にはひずみゲージの位 置の引張力が若干除荷されたためである。

Fig.12(b)の $R=+1.0 \%$ (1 回目) において, 孔周囲補強筋が存在する 位置においては応力度に明らかな違いが見られる。Table8 に示した ように孔周囲補強筋には引張応力度を生じており, せん断に抵抗し たことによって, DBO2.5-w09, DBO2.5-w09-CL は貫通孔の無い DB2.5-w03-CLに比べて耐力低下が遅れたものと考えられる。一方, 孔周囲補強筋の無い区間の $\mathrm{H} 2$ と $\mathrm{H} 1$ では, 3 体とも同程度の応力度 であった。

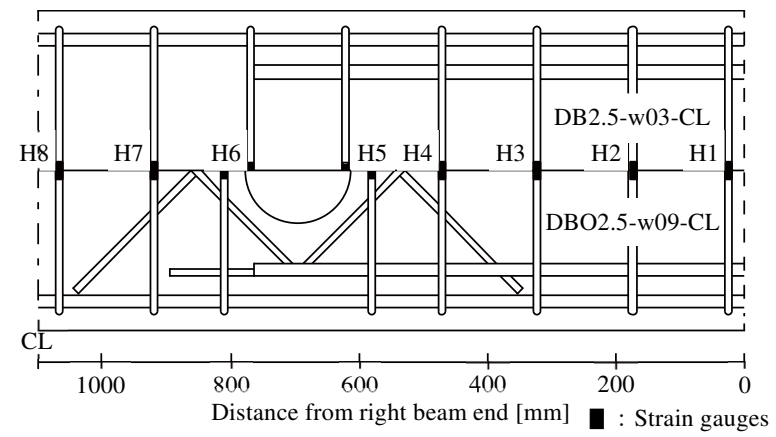

(a) Position of strain gauge

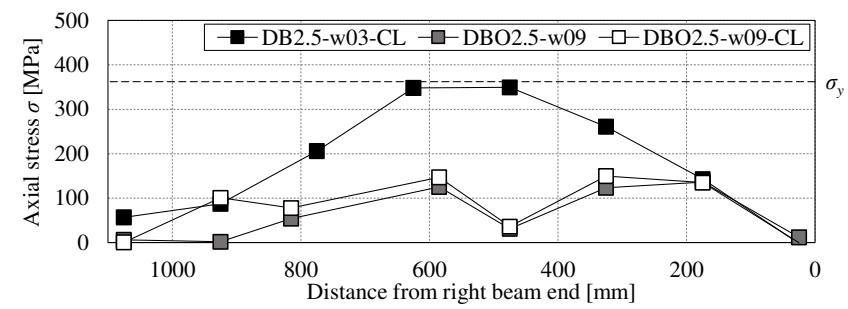

(b) $R=+1.0 \%$ (First cycle)

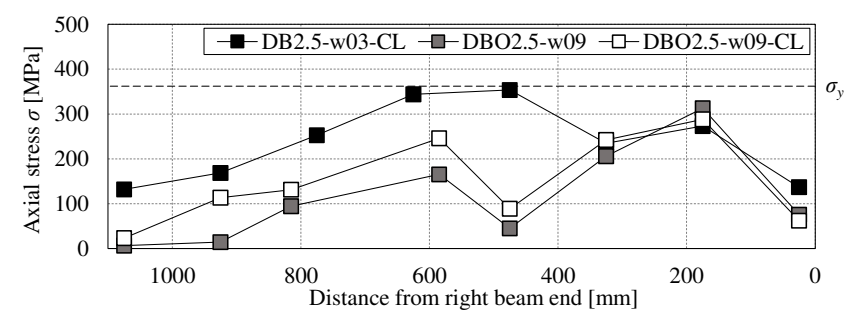

(c) $R=+2.0 \%$ (First cycle)

Fig.12 Tensile stress in shear reinforcement
Fig.12(c)の $R=+2.0 \%$ （1 回目）では，貫通孔を有する試験体は H2 と H3 の応力度が大きくなり, 梁中央部では貫通孔の無い試験体よ りも小さな応力度となっており, 最終破壊性状と整合している。

\section{4 負担せん断力}

4.3 節で述べたように, 孔周囲補強筋の有無で横補強筋の引張応 力度が異なっていた。ここでは, 横補強筋, 孔周囲補強筋, コンク リートのそれぞれが負担するせん断力について考察する。本実験に おける最大耐力は，DB2.5-w03-CL，DBO2.5-w09-CL では部材角 $R=+2.0 \%$ （1 回目）, DBO2.5-w09 では部材角 $R=+1.0 \%$ （1 回目）と 異なっていたが, いずれの試験体も， $+1.0 \%$ （1 回目）と+2.0\%（1 回

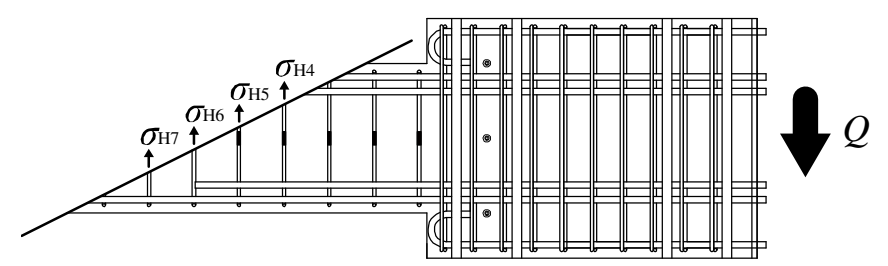

(a) DB2.5-w03-CL

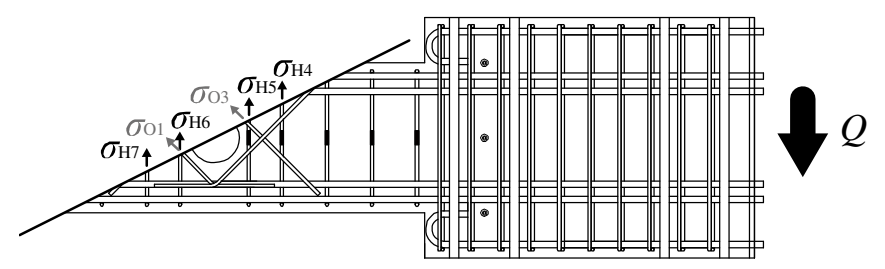

(b) DBO2.5-w09

Fig.13 Specimen with cut line to calculate burdened shear force

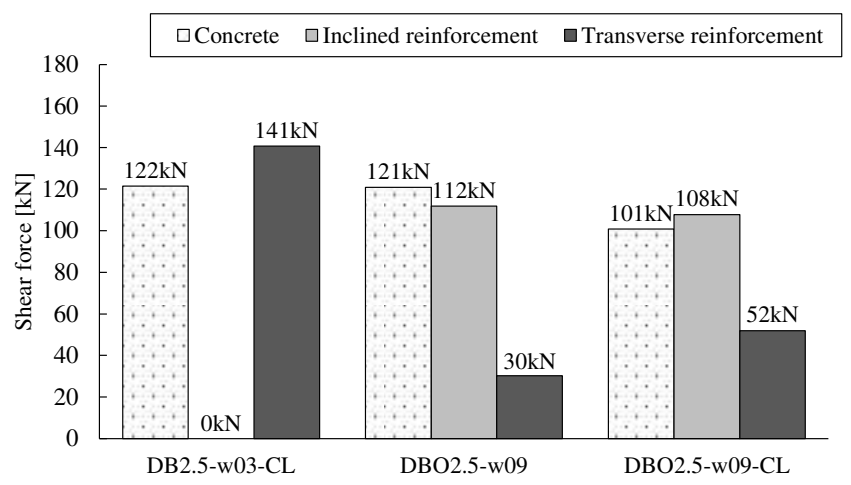

(a) $R=+1.0 \%$ (First cycle)

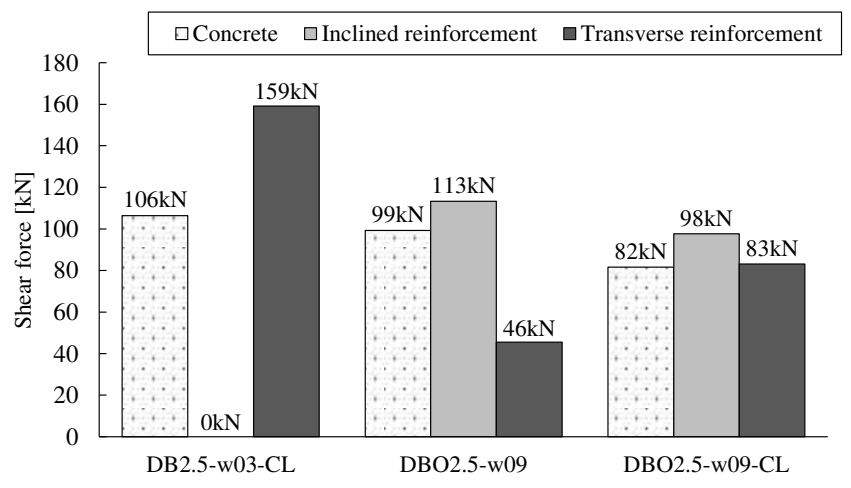

(b) $R=+2.0 \%$ (First cycle)

Fig.14 Shear forces carried by concrete, transverse reinforcement, and inclined reinforcement 
目）のピーク時の荷重はほぼ同じである。しかし，部材角が異なる と, 横補強筋のひずみ度は異なる。そこで, ここでは部材角 $R=+1.0 \%$ (1 回目)， $R=+2.0 \%$ (1 回目) 時の負担せん断力を算出する。負担 せん断力は，鉄筋コンクリート造建物の勒性保証型耐震設計指針・ 同解説 $\left.{ }^{13}\right)$ に基づいてトラス機構のストラット角度 $\phi$ を算出し,

Fig.13 に示すような貫通孔の中心（貫通孔の無い DB2.5-w03-CL で は，ほかの試験体と同じ梁端から 700mm の位置）を通る $\cot \phi=2$ の 傾きの斜線を仮定して算出した。この斜線を横切る横補強筋, 孔周 囲補強筋の負担力を各鉄筋に貼付したひずみゲージにより計測し たひずみの值から算出し，これら 2 つの補強筋負担せん断力の和を 梁のせん断荷重から差し引いたものをコンクリートの負担力とし た。Fig.14 に，部材角 $R=+1.0 \%$ （1 回目），+2.0\%（1 回目）時にお けるコンクリート, 孔周囲補強筋, 横補強筋の負担せん断力を示す。 縦軸はせん断力 $[\mathrm{kN}]$ あ゙あ。

Fig.14 では，DB2.5-w03-CL と DBO2.5-w09-CL を比較すると貫通 孔があることでコンクリートの負担せん断力が減っていることが 分かる。DBO2.5-w09 と DBO2.5-w09-CL を比較すると, 鉄筋をカッ トオフすることで, コンクリートと孔周囲補強筋の負担せん断力が 減り, 横補強筋の負担せん断力が増えている。これは横補強筋が貫 通孔よりも主筋のカットオフ位置に近かったためと考えられる。ま た, DBO2.5-w09 のコンクリートの負担せん断力は, 貫通孔の無い DB2.5-w03-CL と同程度であったが，これはコンクリートの負担せ ん断力に主筋のダボ効果も含まれていること, 圧縮側の孔周囲補強 筋が圧縮力の一部を負担していたことが原因と考えられる。つまり， DB2.5-w03-CL は, Fig.13(a)に示すように梁スパン中央付近で 1 段配 筋となるため, ダボ効果が DBO2.5-w09 より小さかったと考えられ る。また, DBO2.5-w09 では, Table8 に示寸ように圧縮側の孔周囲 補強筋は応力度を生じていたため, コンクリートの余力が多少大き く, コンクリートの負担せん断力が高めに算出されたものと思われ る。

\section{5. 結}

貫通孔と鉄筋のカットオフを有する $\mathrm{RC}$ 梁について，逆対称曲げ 繰り返し加力実験の結果より，以下の結論を得た。

(1) 貫通孔の無い試験体は曲げ降伏後, 付着破壊となった。貫通孔 を有する試験体は, 曲げ降伏後, 孔周囲の斜め補強筋が主筋の 付着応力伝達に寄与したため, 付着破壊ではなく, 孔周囲の斜 め補強筋の無い梁端部でのせん断破壊となった。

（2）貫通孔を有する試験体では孔周囲の斜め補強筋直定着部がせ し断抵抗に寄与したため, 貫通孔の無い試験体よりも良好な 荷重一変形関係となった。

（3） 2 段目カットオフ筋の付着破壊を想定したが，それが先行する 結果にはならなかったため, 2 段目カットオフ筋の付着余裕度 はかなり安全側と考えられる。

（4） せん断破壊した貫通孔を有する梁では，無孔部と有孔部のせ し断余裕度をほぼ同じにしたが，孔周囲の斜め補強筋は降伏 しておらず, 終局せん断耐力計算值は, 無孔部よりも有孔部の 方が安全率は高いと考えられる。

（5）貫通孔を有する梁の 2 段目鉄筋をカットオフ寸ると，貫通孔 位置におけるせん断力の負担割合は，コンクリートと孔周囲
補強筋の負担分が減り，横補強筋の負担分が増えた。

（6）貫通孔周囲の初期せん断ひび割れの発生荷重は, 貫通孔の無 い梁の初期せん断ひび割れの発生荷重よりも低かったが，短 期許容せん断力相当の加力後の除荷 (荷重ゼロ) において, 貫 通孔周囲のせん断ひび割れの残留幅は無孔部よりも狭く，お およそ $0.1 \mathrm{~mm}$ 以下であった。

\section{謝辞}

本研究は, 科学研究費助成事業 (基盤研究 (B)) (課題番号: 19H02282) の助成を受けた研究の一環である。

\section{参考文献}

1) Architectural Institute of Japan: AIJ Standard for Structural Calculation of Reinforced Concrete Structure, 2018 (in Japanese) 日本建築学会: 鉄筋コンクリート構造計算規準・同解説, 2018

2) Research Committee of Perforated Beams: Research of Reinforced Concrete Beams with Perforations, Part 10 Experimental Formula for Shearing Strength of Perforated Beams, Transaction of Architectural Institute of Japan, No. 69, pp. 541-544, 1961. 10 (in Japanese) 有孔ばり研究委員会, 松下清夫, 黒正清治: 鉄筋コンクリート有孔ばり に関する研究, その 10 終局強度実験式, 日本建築学会論文報告集, 第 69 号, pp. 541-544, 1961. 10

3) Arakawa, S.: Tekkinkonkuriitobari No Kyoyousendan-ouryokudo To Sendanhokyou Ni Tsuite, Jikkenkekka Niyoru Saikentou, Concrete Journal, Japan Concrete Institute, Vol. 8, No. 7, pp. 11-20, 1970. 7 荒川卓: 鉄筋コンクリートばりの許容せん断応力度とせん断補強につい て, 実験結果による再検討, コンクリートジャーナル, 日本コンクリー 卜工学協会, Vol. 8, No. 7, pp. 11-20,1970.7

4) Architectural Institute of Japan: Tekkinkonkuriito Shuukyokukyoudosekkei Ni Kansuru Siryou, 1987

日本建築学会：鉄筋コンクリート終局強度設計に関する資料, 1987

5) Tsumura, K.: Shear Behavior of Reinforced Concrete Beams with Openings Influence of Shear Span Ratio and Position of Opening-, Journal of Structural and Construction Engineering (Transaction of AIJ), No. 407, pp. 47-59, 1990. 1 津村浩三: 鉄筋コンクリート有孔梁のせん断破壊に関する研究-せん断 スパン比及び開口位置の影響-, 日本建築学会構造系論文報告集, 第 407 号, pp. 47-59, 1990. 1

6) Tsumura, K.: Shear Strength of Reinforced Concrete Beams with Openings, Journal of Structural and Construction Engineering (Transaction of AIJ), No. 424 , pp. $35-46,1991.6$ 津村浩三：開口を有する鉄筋コンクリート造のせん断耐力，日本建築学 会構造系論文報告集，第 424 号, pp. 35-46, 1991.6

7) Suruga, R., Kurosawa, T., Igarashi, H., Morimoto, T., Watanabe, T., Yamamoto, K., Iwakura, T.: Shear/ Bending Test of Reinforced Concrete Beams with Openings at Plastic Hinge Areas, Part 3 Study on a Capacity of Deformation, Summaries of Technical Papers of Annual Meeting, Architectural Institute of Japan, Structure IV, pp. 225-226, 2002. 7 (in Japanese) 駿河良司, 黒沢俊也, 五十嵐治人, 森本敏幸, 渡辺朋之, 山本憲一郎, 岩 倉知行: 梁端部ヒンジ領域に開口を有する $\mathrm{RC}$ 梁の曲げせん断実験, そ の 3 変形性能確認実験, 日本建築学会大会学術講演梗概集, 構造 IV, pp. 225-226, 2002.7

8) Dou, Z., Matsumori, T., Otani, S.: Experiment for Shear Strength of R/C Beams with Opening in Plastic Hinge Region, Part 2 Discussion on Test Result, Summaries of Technical Papers of Annual Meeting, Architectural Institute of Japan, Structure IV, pp. 223-224, 2002. 7 (in Japanese)

Dou Zurong, 松森泰造，小谷俊介：ヒンジ領域に開孔を設けた梁のせん 断耐力に関する実験, その 2 実験結果の検討, 日本建築学会大会学術講 演梗概集, 構造 IV, pp. 223-224, 2002.7

9) Ishikawa, Y., Hirabayashi, M., Kinoshita, T., Asou, N., Nakane, K., Shishido, S., Ogura, F.: R/C Beam-Column Joints using double rayed beam bars with headed 
anchor to relocate beam plastic hinges, Summaries of Technical Papers of Annual Meeting, Architectural Institute of Japan, Structure IV, pp. 745-746, 2013. 7 (in Japanese)

石川裕次, 平林聖尊, 木下拓也, 麻生直木, 中根一臣, 实戸覚, 小倉史崇: 梁 2 段筋に機械式定着を用いたヒンジリロケーション柱梁接合部, 日本 建築学会大会学術講演梗概集, 構造 IV, pp. 745-746, 2013.7

10) Shibao, K., Nakada, M., Kajiwara, R., Nishimura, K.: Loading Test on RC Beam with Longitudinal Bars Cut Off and Lap Splice, Part 2 Influence of Opening, Summaries of Technical Papers of Annual Meeting, Architectural Institute of Japan, Structure IV, pp. 153-154, 2020.7 (in Japanese)

柴尾海斗, 中田幹久, 梶原僚太, 西村康志郎: 鉄筋のカットオフ・重称継 手を有する $\mathrm{RC}$ 梁の静的加力実験, その 2 開口の影響, 日本建築学会大 会学術講演梗概集, 構造 IV, pp. 153-154, 2020.7

11) Nagayama, K., Bunno, M., Jung, M., Maeda, M., Tasai, A., Nagata, M.: An Evaluation of Residual Seismic Capacity of Reinforced Concrete Buildings Based on the Damage of Columns, Part 2 The Relation between the Residual Crack Width and the Deformation of the Member, Summaries of Technical Papers of Annual Meeting, Architectural Institute of Japan, Structure IV, pp. 453-454, 2001.7 (in Japanese)

永山憲二, 文野正裕, 鄭文淑, 前田匡樹, 田才晃, 長田正至: 柱部材の損 傷状態に基づく震災 RC 造建築物の残余而震性能評価, その 2 実験概要 及び結果, 日本建築学会大会学術講演梗概集, 構造 IV, pp. 453-454, 2001. 7

12) Ito, A., Hasegawa, K., Suzuki, Y., Takahashi, S., Ichinose, T.: Splitting Bond Strength of RC Beam of Which Second Layer Bars Are Cut Off, Journal of Structural and Construction Engineering (Transaction of AIJ), Vol. 78, No. 690, pp. $1477-1484,2013.8$

伊藤彩夏, 長谷川桂亮, 鈴木悠矢, 高橋之, 市之瀬敏勝: 2 段目主筋を力 ットオフした RC 梁主筋の付着割裂強度, 日本建築学会構造系論文集, 第 78 巻, 第 690 号, pp. 1477-1484, 2013. 8

13) Architectural Institute of Japan: Design Guidelines for Earthquake Resistant Reinforced Concrete Buildings Based on Inelastic Displacement Concept, 1999 (in Japanese)

日本建築学会：鉄筋コンクリート造建物の鞋性保証型耐震設計指針・同 解説, 1999 


\title{
EXPERIMENTAL STUDY ON STRUCTURAL PERFORMANCE OF RC BEAM WITH OPENING AND LONGITUDINAL CUT OFF BARS
}

\author{
Kaito SHIBAO ${ }^{* 1}$ and Koshiro NISHIMURA *2 \\ ${ }^{* 1}$ Former Grad. Student, Tokyo Institute of Technology, M.Eng. \\ ${ }^{2}$ Assoc. Prof., Tokyo Institute of Technology, Dr.Eng.
}

We often construct reinforced concrete beams with openings for plumbing, and the longitudinal bars are spliced or cut off within the beams. As designing a building structure of reinforced concrete, we verify bond around cut off bars and, lap splices, and shear capacities around openings, each by each. Although these parts are weak points in the beam, we don't pay much attention to the combined influence among them. If an opening is close to a discontinuous point generated by cutting off the bar or lap splicing, they may influence each other. On the other hand, in order to verify serviceability and repairability, allowable shear capacities for a RC beam with opening have been added to AIJ Standard for Structural Calculation of Reinforced Concrete Structure (2010). Because examination on the allowable shear capacities with the test data are limited, more data of $\mathrm{RC}$ beams with opening are required to make clear a relationship between cracks on the concrete surface and structural performance of the beams. In this study, we investigated the influences of longitudinal bars cut off and lap splice in a beam with opening. We prepared three RC beam specimens, and applied anti-symmetric bending in both positive and negative directions repeatedly and statically. The specimens were scaled down by about a half. Test parameters are the presence of openings and the presence of discontinuous points generated by cutting off bars or lap splicing. One specimen had two openings and the discontinuous points of bars, another had two openings but no discontinuous points of bars, the other had the discontinuous points of bars but no openings. The following conclusions were obtained from the experimental results.

(1) The specimen without opening, after flexural yielding, failed in bond between longitudinal bars and concrete. The specimens with opening, after flexural yielding, failed in shear at the beam end region, not at the opening. That is because the inclined reinforcement transferred bond stress around the longitudinal bars.

(2) The load-deformation curves of the beams with opening were better than that of the beam without opening because the embedded part of the inclined reinforcement contributed to the resistance to shear load.

(3) It is considered that the margin of bond capacity on inner cut-off bar is on the safe side considerably because the beam failed in shear though we designed the beams to fail in bond around inner cut-off bars.

(4) The beams failed in shear had almost the same ratio of calculated shear capacity to required value at the opening as at the region without opening. However, the inclined reinforcement around opening didn't yield. It is considered that the margin of the shear capacity in the region with opening is higher than the region without opening.

(5) When the inner bar of the beam with opening was cut off, shear forces resisted by concrete and inclined reinforcement decreased, and shear force resisted by transverse reinforcement increased.

(6) The load when an initial shear crack occurred around opening was lower than the load when an initial shear crack occurred on the beam without opening. However, the width of shear cracks around openings was less than approximately $0.1 \mathrm{~mm}$ after unloading from the load of allowable shear capacity, which the width was narrower than that in the region without opening. 